\title{
Innovation in floriculture with ornamental plants from Caatinga biome ${ }^{(1)}$
}

\author{
MÁRKILLA ZUNETE BECKMANN-CAVALCANTE(2)*, JOÃO HENRIQUE FERREIRA SABINO(2), \\ MAYARA SUZANNE DE MELO BARBOSA ${ }^{(2)}$, DANIEL FAGNER DA SILVA DULTRA(2), HANDERSON LEANDRO \\ DA COSTA SILVA(2), SHEILA DANIELLA PEREIRA DA SILVA ${ }^{(2)}$, ELISABETH REGINA TEMPEL STUMPF(3)
}

\begin{abstract}
The Caatinga biome which presents a singular vegetation found only in Brazil has a diversity of vegetal species with uses not yet explored. In this sense, the objective was to study two species of the Caatinga biome to be used as cut flowers. The work was developed at the Agricultural Sciences Campus of the Federal University of the São Francisco Valley, Petrolina, PE. Based on previous studies, two endemic species of the Caatinga biome were selected: Neoglaziovia variegata and Senna martiana. The evaluation criteria were based on the length, stiffness and appearance of the stems; form of flower, fruit or leaf; income in floral composition; color or brightness; scent; originality; and real life in water and floral foam. For these characteristics grades were assigned $(0,5$ and 10) and after classified for ornamental potential (high, medium, low and minimum ornamental potential). The results showed that the species $N$. variegata and S. martiana reached 80 and 85 points, respectively, classifying them as high ornamental potentiality. As such, they can be used as cut flower.
\end{abstract}

Keywords: Neoglaziovia variegata, Senna martiana, floral art, floriculture, semiarid.

\section{RESUMO}

Inovação na floricultura com plantas ornamentais do Bioma Caatinga

O Bioma Caatinga, que apresenta uma vegetação singular, encontrada apenas no Brasil, possui diversidade de espécies vegetais com usos ainda não explorados. Nesse sentido, objetivou-se estudar espécies da flora da Caatinga para serem utilizadas como flores de corte. O trabalho foi desenvolvido no Campus de Ciências Agrárias da Universidade Federal do Vale do São Francisco, Petrolina, PE. Baseado em estudos prévios foram selecionadas duas espécies endêmicas do Bioma Caatinga: Neoglaziovia variegata e Senna martiana. Os critérios de avaliação foram baseados no comprimento, rigidez e aparência das hastes; forma da flor, fruto ou folha; rendimento na composição floral; cor ou brilho; aroma; originalidade; e, vida útil real na água e espuma floral. Para estas características foram atribuídas notas $(0,5$ e 10) e, posteriomente, classificadas quanto ao potencial ornamental (alta, média, baixa e mínima potencialidade ornamental). Pelos resultados obtidos, a espécie $N$. variegata e $S$. martiana obtiveram 80 e 85 pontos respectivamente, classificando-as como de alta potencialidade ornamental. Sendo assim, podem ser utilizadas como flor de corte.

Palavras-chave: Neoglaziovia variegata, Senna martiana, arte floral, floricultura, semiárido.

\section{INTRODUCTION}

Temperate flowers have always possessed the highest volume of commercialization worldwide, including in Brazil. This situation is due to the historical tradition in the use of exotic plants, whose cultivation and maintenance processes have been greatly dominated for long time (STUMPF et al., 2009). Accordingly Beruto (2013) the floriculture industry looks for new species with ornamental potential that become competitive in the market. Also emphasized that annually hundreds of new cultivars are released and/or evaluated in different parts of the world to renew the need for the demand and supply of ornamental plants.

Introduction of new cut flower crops not only attracts the consumers and conserve natural ecosystems, but also provide more options to the growers and marketing stakeholders. The use of endemic and native species offers many advantages: plants are acclimatized to local conditions for production, are more resistant to pests and diseases and have fewer inputs requirements for successful production (BERUTO, 2013; DRAGOVIC, 2015). Conforming Stumpf et al. (2008) and Beruto (2013), both cut flowers and foliage should exhibit beauty, innovation, balanced architecture, coloration that allow multiple combinations, quality of the stem length that meets different proposals of use and have reasonably longer vase life, support long distance transportation and possible to store for a long time are well recommended to the floriculture industry for fulfilling the customers' aesthetic needs.

Brazil hosts the most megadiverse flora in the world (FORZZA et al., 2012) and several researches

DOI: http://dx.doi.org/10.14295/oh.v23i3.1081

(1) Received in 05/07/2017 and accepted in 06/09/2017

${ }^{(2)}$ Universidade Federal do Vale do São Francisco, Departamento de Engenharia Agronômica, Petrolina-PE, Brazil. *Corresponding author: markilla. beckmann@univasf.edu.br

${ }^{(3)}$ Instituto Federal de Educação, Ciência e Tecnologia Sul-Rio-grandense, Pelotas-RS, Brazil.

Licensed by CC BY 4.0 
with native species for ornamental use presented positive results, highlighting prospects as innovation in the national floriculture market (LEAL and BIONDI, 2006; CARDOSO and ISRAEL, 2005; CASTRO and CAVALCANTE, 2010; STUMPF et al., 2007; 2008; TOMBOLATO, 2008; STUMPF et al., 2009; KIILL et al., 2013; MOREIRA et al., 2017).

The Caatinga biome is represented by about of 5000 species with an expressive number of endemic species (around 380) (SIQUEIRA FILHO, 2012). Which although it seems inhospitable is still a lot to find out about the flora of this biome, because reveals a biota full of adaptive mechanisms, being little explored by the science and also for economic development of this biodiversity (SIQUEIRA FILHO, 2012; ALVAREZ and KIILL, 2014). Cavalcante et al. (2017) pointed out numerous species of several botanical families inserted in this biome which presents ornamental characteristics suitable for use as ornamental plants, mainly for landscape use.

Although the Caatinga presents species that can be used as ornamental crops, information is still rare on the use of local species for pot- and cut flower and foliage production. There is a need for a differentiated look for the native plants and in the future to become options for the Floriculture market and in addition to generate more specific information for producers to grow such crops. Therefore, the objective of this study was to screen out two potential species (Neoglaziovia variegate and Senna martiana) commonly grown in Caatinga Biome to be used as cut flowers.

\section{MATERIAL AND METHODS}

The selection of species Neoglaziovia variegata (Arruda) Mez (Bromeliaceae) and Senna martiana (Benth.) H.S. Irwin \& Barneby (Fabaceae) was carried out based on previous studies with plants of the Caatinga Biome for ornamental use and was observed the beauty and natural longevity of the flower stems in the field (CAVALCANTE et al., 2017).

Healthy and vigorously growing flower stems of $N$. and S. martiana, each one at different times of the year were harvested from different sites at the Campus of Agrarian Sciences of the Federal University of São Francisco Valley. The occurrence sites in this study were situated between the parallels $9^{\circ} 19^{\prime} 12.1^{\prime \prime}$ and $9^{\circ} 20^{\prime} 20.6^{\prime \prime} \mathrm{S}$ and between the meridians $40^{\circ} 32^{\prime} 22.6^{\prime \prime}$ and $40^{\circ} 33^{\prime} 44.9^{\prime \prime} \mathrm{W}$. According to Köppen's classification, the local climate is "Bswh" (semiarid), with rainfall lower than $500 \mathrm{~mm}$ concentrated in three or four months of the year, average sunshine of 2800 hours.year $^{-1}$, average annual temperatures from $23^{\circ}$ to $27^{\circ} \mathrm{C}$, evaporation of $2000 \mathrm{~mm}$.year ${ }^{-1}$ and relative humidity of the average air around 50\% (MOURA et al., 2007).

The suitability of use in floral art was verified for the flower stems collected according to the methodology proposed by Stumpf et al. (2007). To determine the degree of potential use for cut flower for accessions studied, a grading of aesthetic characteristics was allocated with 0 : not good, 5: medium and 10: very good (Table 1). This methodology was used to describe the stem length, stiffness, general appearance, form of flower, fruit or leaf, income in floral composition, color/brightness, scent, originality and the real vase life in water and floral foam.

Table 1. Method for evaluating the ornamental potentiality of native and non-conventional species proposed by Stumpf et al. (2007b), based on the attribution of 0,5 or 10 points to each of the features of interest for floral art and the consumer market.

\begin{tabular}{|c|c|c|c|}
\hline \multirow{2}{*}{ Features } & \multicolumn{3}{|c|}{ Grades } \\
\hline & $\mathbf{0}$ & 5 & 10 \\
\hline Length & Less than $20 \mathrm{~cm}$ & Between 20 and $40 \mathrm{~cm}$ & Greater than $40 \mathrm{~cm}$ \\
\hline $\begin{array}{l}\text { Stiffness of the } \\
\text { flower stem }\end{array}$ & $\begin{array}{l}\text { Flexible, it needs reinforcement } \\
\text { to be used }\end{array}$ & $\begin{array}{l}\text { Semi-rigid, it needs reinforcement } \\
\text { according to the use }\end{array}$ & $\begin{array}{l}\text { Firm, it does not need } \\
\text { reinforcement }\end{array}$ \\
\hline $\begin{array}{l}\text { Flower stem } \\
\text { aspect }\end{array}$ & $\begin{array}{l}\text { It interferes negatively in the } \\
\text { floral composition, should not be } \\
\text { exposed or in evidence }\end{array}$ & $\begin{array}{l}\text { It does not interfere in the floral } \\
\text { composition or adds value to floral } \\
\text { compositions }\end{array}$ & $\begin{array}{l}\text { It positively interferes in the } \\
\text { floral composition, adds value to } \\
\text { floral compositions or contributes } \\
\text { positively to aesthetics }\end{array}$ \\
\hline $\begin{array}{l}\text { Flower or } \\
\text { inflorescence } \\
\text { shape }\end{array}$ & $\begin{array}{l}\text { Unattractive or it is not the main } \\
\text { ornamental feature }\end{array}$ & $\begin{array}{l}\text { Common or the valorization } \\
\text { depends on the combination } \\
\text { with other elements of the floral } \\
\text { composition }\end{array}$ & $\begin{array}{l}\text { Unusual or it adds value to floral } \\
\text { compositions }\end{array}$ \\
\hline $\begin{array}{l}\text { Income in floral } \\
\text { composition }\end{array}$ & $\begin{array}{l}\text { Low, it contributes little to } \\
\text { increase the volume of floral } \\
\text { composition }\end{array}$ & $\begin{array}{l}\text { Medium, it contributes moderately } \\
\text { to increase the volume of floral } \\
\text { composition }\end{array}$ & $\begin{array}{l}\text { High, it contributes positively } \\
\text { to increase the volume of floral } \\
\text { composition }\end{array}$ \\
\hline $\begin{array}{l}\text { Color and/or } \\
\text { brightness of } \\
\text { the flower or } \\
\text { inflorescence }\end{array}$ & $\begin{array}{l}\text { Unattractive or they are not the } \\
\text { main ornamental feature }\end{array}$ & $\begin{array}{l}\text { Common or the valorization } \\
\text { depends on the combination } \\
\text { with other elements of the floral } \\
\text { composition }\end{array}$ & $\begin{array}{l}\text { Unusual or they add value to floral } \\
\text { compositions }\end{array}$ \\
\hline Scent & Slightly pleasant & No scent or despicable & $\begin{array}{l}\text { Pleasant, it can add value to floral } \\
\text { compositions }\end{array}$ \\
\hline Originality & & There is similar in the market & There is no similar in the market \\
\hline Vase life & Less than 10 days & Between 10 and 15 days & More than 15 days \\
\hline
\end{tabular}


The stem length of the collected material was determined by a millimeter rule, measuring the entire length, from the base to the top. The stiffness of the flower stem is related to the need for artificial support to keep the material erect, while its aspect is related to the visual effect that it is capable of causing in floral composition. In the same way, the shape of the flower or inflorescence describes the visual effect that this structure causes in floral composition. The income refers to the volume that adds to the floral composition and the quantity of usable structures. Additionally, the color and brightness of the structures present in the stems were evaluated by comparison with CMYK color scale. Besides these features, the scent of the species was analyzed through olfactory perception and originality with traditional ornamental species on the market.

Finally, the vase life evaluation of the flower stems was carried out, which consisted of the determination of the time, in days, from the time of field collection to the discard of the stems due to the loss of the features of ornamental interest. In the latter analysis, the stems were conditioned in containers with urban sanitation water and also floral foam, both kept in an uncontrolled environment. Five stems with flowers in various stages of maturity with four repetitions were used. The vase life, in this methodology, was a preliminary evaluation to verify the possibilities of a future use as a cut flower.
After that, the grade was summed and then the ornamental potential degree was verified. A score of more than 70 points showed high ornamental potential degree, between 50 and 70 points, medium potential, between 25 and 50 , low potential and less than 25 , minimum potential.

\section{RESULTS AND DISCUSSION}

The N. variegata (Figure 1) species belongs to the family Bromeliaceae, endemic of the Caatinga biome, being widely distributed in the Northeastern States of Brazil and part of Minas Gerais (PEREIRA and QUIRINO, 2008). Despite the evident beauty of $N$. variegata flower stems, whose inflorescence has reddish scape (CMYK 10100-50-0) measuring approximately $50 \mathrm{~cm}$ in height with small flowers of reddish chalice and lilac corolla (CMYK 80-100-30-0), this species is still little studied and explored for its potential ornamental (CAVALCANTE et al., 2017). This specie is commonly known by the Brazilian Northeastern population as "caroá" and is more approached in the academic environment owing to its leaves used in fiber extraction (PAULA and GUARÇONI, 2007; ALMEIDA et al., 2008; SILVEIRA et al., 2009; SILVEIRA et al., 2013). The inflorescences stems are emitted in the transition period between the end of the drought season and the beginning of the rainy season (PEREIRA and QUIRINO, 2008).
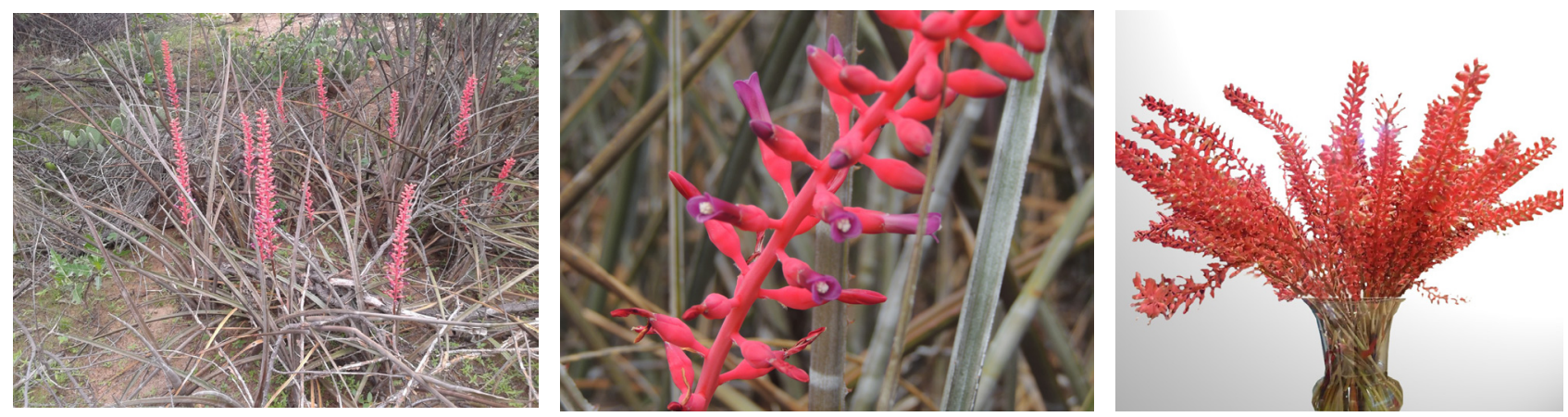

Figure 1. Neoglaziovia variegata (Arruda) Mez (Bromeliaceae). A. Plant habit and details of leaf shape. B. Details of flowers and cut stems. C. Floral composition.

Photos: H.L.C.S. and S.D.P.S.

S. martiana (Figure 2) known as "canafístula de lajedo" belongs to the Fabaceae family, being also endemic to the Caatinga biome and widely distributed in most Northeastern Brazilian states (SOUZA and BORTOLUZZI, 2011) and generally associated with rocks environments. It is a shrub plant with a large canopy and rapid growth, reaching a height of 1.5 to 4 meters. Although it is morphologically similar to other species of the same genus, its inflorescences and fruits are more abundant and exuberant (MACEDO et al., 2009). It has a racemic axial inflorescence with yellow flowers (CMYK 0-0-100-0) of the standard type, where its developed bracts protect the obovate bud. AndradeLima (1989) cites that several species of the genus Senna, including $S$. martiana are cultivated as ornamental. However, even with its remarkable ornamental potential, research on $S$. martiana is still more focused on its chemical components of pharmaceutical interest (MACEDO et al., 2009; MACEDO et al., 2016). 

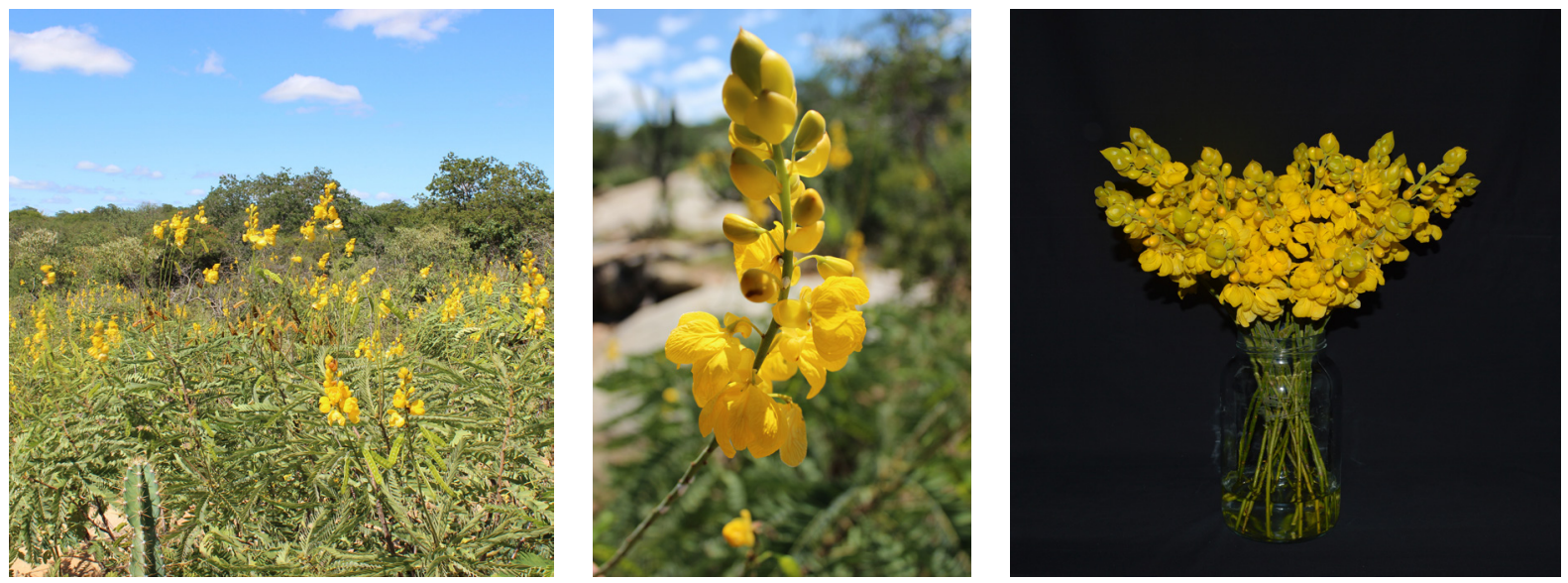

Figure 2. Senna martiana (Benth.) H.S. Irwin \& Barneby (Fabaceae). A. Plant habit.

B. Details of flowers and cut stems. C. Floral composition.

Photos: H.L.C.S. and S.D.P.S.

The scores obtained by each species evaluated for the features of ornamental interest, as well the total score, are described in Table 2. For the parameter length of flower stem, both species under study acquired the maximum score (10 points), since they have length averages higher than $40 \mathrm{~cm}$. According to Stumpf (2008), values such as these allow a wide use in floral compositions, providing the chance to create different styles and formats.

Table 2. Scores reached by the flower stems of Neoglaziovia variegata and Senna martiana as regards the features of ornamental interest evaluated.

\begin{tabular}{|c|c|c|}
\hline \multirow{2}{*}{ Features } & \multicolumn{2}{|c|}{ Scores } \\
\hline Stem length & $\begin{array}{c}\text { Neoglaziovia } \\
\text { variegata }\end{array}$ & Senna martiana \\
\hline Stiffness of the flower stem & 10 & 10 \\
\hline Flower stem aspect (general appearence) & 10 & 10 \\
\hline Form of flower, fruit or leaf & 10 & 10 \\
\hline Income in floral composition & 10 & 10 \\
\hline Color and/or brightness of the flower or & 10 & 10 \\
\hline inflorescence & 10 & 10 \\
\hline Scent & 5 & 10 \\
\hline Originality & 10 & 85 \\
\hline Real vase life in water & 50 & 0 \\
\hline Real life in floral foam & 5 & 5 \\
\hline Final Score & & 5 \\
\hline
\end{tabular}


Regarding the stiffness of the flower stem, both $N$. variegata and $S$. martiana did not require the use of artificial support to maintain a vertical position, allowing the acquisition of a maximum mark for both. For Chamas and Matthes (2000), this characteristic is directly associated with the ability of stems to remain attractive and aesthetically viable when they are handled or transported. Furthermore, it is observed that more flexible stems are need greater care in order not to be damaged (STUMPF, 2008).

The species were classified as valuable aggregates to the floral compositions regarding the aspect of the flower stem, since they contributed positively with their aesthetic attributes. As stated by Cavalcante et al. (2017), S. martiana is a shrub species with ornamental potential as a result of its differentiated shape, color and volume.

Regarding to the general appearance, the species contribute positively to add aesthetic value to the floral composition. As with the species Eryngium (STUMPF et al., 2008), the stems of the species evaluated in the present work have characteristics of coloration, length, stiffness and texture (smooth) favorable to use in linear compositions (ikebana type), transmitting verticality and simplicity in their lines.

Both species under study received maximum score (10 points) for income in floral composition since the size and quantity of flowers contributes positively to increase the volume of floral composition (Figure 1 and Figure 2), although the stems not have secondary branches.

The inflorescences of $N$. variegata and $S$. martiana revealed that the first one have no scent and the second presents a slightly perceptible scent, as a consequence they acquired 5 and 10 points, respectively. Other studies have also reported the absence of perceptible scent for N. variegata (PEREIRA and QUIRINO, 2008) and the presence for $S$. martiana (CAVALCANTE et al., 2017).

The originality was also another prominent factor for the evaluated species, mainly because of the singularity of the colors and shapes of their stems. Moreover, there is no similarity with any other species in the regional and even national market. According to Cavalcante et al. (2017), the original features of $N$. variegata afford the opportunity for its flower stems and leaves to be used for both landscaping and floral art purposes.

The real vase life performance in water was ten days for both $N$. variegata and $S$. martiana, being thus assigned the average mark with 5 points but on the other hand, the real life in floral foam was 7 and 8 days, respectively, without points. As indicated by Stumpf et al. (2009) for native and non-conventional species, there is no information on how long ornamental features should remain adequate after harvesting of their flower stems. However, Weiss (2002) argue that a flower should remain vigorous and attractive for at least one week for the final consumer, i.e. it must remain with suitable aesthetic characteristics for more than seven days from its acquisition in commerce.

The two species under study received scores higher than 70 points, which the S. martiana and N. variegata scored 85 and 80 , respectively. Therefore, these native species of the Caatinga biome were classified as being of high ornamental potential degree. Taking into account the high degree of potentiality of these species, accordingly Stumpf et al. (2008) features like propagation, cultivation and management should be in order to enable it to be placed on the Floriculture market.

\section{CONCLUSIONS}

The Caatinga biome have species with ornamental potential, such as Neoglaziovia variegata and Senna martiana, which own floral stems suitable and differentiated for use in floral arrangements.

The aesthetic attributes of Neoglaziovia variegata and Senna martiana and its real vase life attests the suitability of these species for use in floral arrangements. Also, they can collaborate to innovate floral styles.

\section{ACKNOWLEDGMENTS}

To the Federal University of the São Francisco Valley (UNIVASF) due to research support for the Universal Doctor Program (Announcement No. 19/2013). To the National Council for Scientific and Technological Development (CNPq), for the financial aid and grant of scholarships. To the CRAD (Centro de Referência para Recuperação de Áreas Degradadas) team to collaborate with the correct identification of the species.

\section{AUTHORS CONTRIBUTIONS}

M.Z.B.C.: Experiment idealization, implementation and conduction; data analysis; manuscript writing. J.H.F.S.: manuscript writing and review. M.S.M.B.: manuscript writing and review. D.F.S.D.: Experiment implementation and conduction; data collection. H.L.C.S.: Experiment conduction and photos. S.D.P.S.: Experiment conduction and photos. E.R.T.S.: Experiment idealization; manuscript review.

\section{REFERENCES}

ALMEIDA, J.R.M.; ALMEIDA, A.L.F.S.; CARVALHO, L.H. Mechanical, morphological, and structural characteristics of caroa (Neoglaziovia variegata) fibres. Polymers \& Polymer Composites, v.16, n.9, p.589-595, 2008.

ALVAREZ, I.A.; KIILL, L.H.P. Arborização, floricultura e paisagismo com plantas da Caatinga. Informativo Abrates, v.24, p.63-67, 2014.

ANDRADE-LIMA, D. de. Plantas das caatingas. Rio de Janeiro: Academia Brasileira de Ciências, 1989. 243p.

BERUTO, M. Introduction of new ornamental plants and production technologies: case studies. Acta Horticulturae, v.1000, p.23-34, 2013. 
CARDOSO, J.C.; ISRAEL, M. Levantamento de espécies da família Orchidaceae em Águas de Sta. Bárbara (SP) e seu cultivo. Horticultura Brasileira, v.23, n.2, p.169-173, 2005.

CAStro, A.S.; CAVAlCANTE, A. Flores da Caatinga. Campina Grande: INSA, 2010. 114p.

CAVALCANTE, M.Z.B.; DULTRA, D.F.S.; SILVA, H.L.C.; COTTING, J.C.; SILVA, S.D.P.; SIQUEIRA FILHO, J.A. Potencial ornamental de espécies do Bioma Caatinga. Comunicata Scientiae, v.8, n.1, p.43-58, 2017. DOI: $<10.14295 / C S . v 8 i 1.2649>$

CHAMAS, C.C.; MATTHES, L.A.F. Método para levantamento de espécies nativas com potencial ornamental. Revista Brasileira de Horticultura Ornamental, v.6, p.53-63, 2000.

DRAGOVIC, M.J.O. Selection and domestication of endemic species from macaronesia with ornamental value. Acta Horticulturae, v.1097, p.193-198, 2015.

FORZZA, R.C.; BAUMGRATZ, J.F.A.; BICUDO, C.E.M.; CANHOS, D.A.L.; CARVALHO JR., A.A.; COELHO, M.A.N.; COSTA, A.F.; COSTA, D.P.; HOPKINS, M.G.; LEITMAN, P.M.; LOHMANN, L.G.; LUGHADHA, E.N.; MAIA, L.C.; MARTINELLI, G.; MENEZES, M.; MORIM, M.P.; PEIXOTO, A.L.; PIRANI, J.R.; PRADO, J.,; QUEIROZ, L.P.; SOUZA, S.; SOUZA, V.C.; STEHMANN, J.R.; SYLVESTRE, L.S.; WALTER, B.M.; ZAPPI, D.C. New Brazilian floristic list highlights conservation challenges. BioScience, v.62, p.39-45, 2012.

KIILL, L.H.P.; TERAO, D.; ALVAREZ, I.A. Plantas ornamentais da Caatinga. Brasília: Embrapa Semiárido, 2013. 139p.

LEAL, L.; BIONDI, D. Potencial ornamental de espécies nativas. Revista Científica Eletrônica de Engenharia Florestal, n.8, 2006.

MACEDO, E.M.S.; SILVA, J.G.A.E.; SILVA, M.G.V. Chemodiversity and Biopharmacological Properties of Native Species of in Northeastern Brazil. Revista Virtual de Química, v.8, n.1, p.169-195, 2016. DOI: $<10.5935 / 1984-6835.20160012>$

MACEDO, E.M.S.; WIGGRES, H.J.; SILVA, M.G.V. ; BRAZ FILHO, R.; ANDRICOPULO, A.D.; MONTANARI C.A.A new bianthron glycoside as inhibitor of Trypanosoma cruzi glyceraldehyde 3-phosphate dehydrogenase activity. Journal of the Brazilian Chemical Society, v.20, p.947953, 2009. DOI: <http://dx.doi.org/10.1590/S0103$50532009000500021>$
MOREIRA, F.C.; OLIVEIRA, M.N.S.; TANAKA, M.K. Development of everlasting flowers (Comanthera elegans (Bong.) L.R. Parra \& Giul.) in three cultivation systems. Ornamental Horticulture, v.23, n.2, p.117-126, 2017. DOI: <http://dx.doi.org/10.14295/oh.v23i2.979>

MOURA, M.S.B.; GALVINCIO, J.D.; BRITO, L.T.L.; SOUZA, L.S.B.; SÁ, I.I.S.; SILVA, T.G.F. Clima e água de chuva no semi-árido. In: BRITO, L.T.L.; MOURA, M.S.B.; GAMA, G.F.B. Potencialidades da água de chuva no Semi-Árido Brasileiro. Petrolina: Editora Embrapa SemiÁrido, 2007. p.35-59.

PAULA, C.C.; GUARÇONI, E.A.E. Neoglaziovia variegata: a fiber producing Brazilian Bromeliad. Journal of the Bromeliad Society, v.57, p.119-120, 2007.

PEREIRA, F.R.L.; QUIRINO, Z.G.M. Fenologia e biologia floral de Neoglaziovia variegata (Bromeliaceae) na Caatinga Paraibana. Rodriguésia, v.59, n.4, p.835-844, 2008.

SILVEIRA, D.G.; LINO, L.S.M.; SOUZA, A.S.; SOUZA, F.V.D. Somatic Embryogenesis of Neoglaziovia variegata (Arruda) Mez, an important source of fiber from native Brazilian bromeliads. Brazilian Archives of Biology and Technology, v.56 n.4, p.547-555, 2013. DOI: <http:// dx.doi.org/10.1590/S1516-89132013000400004>

SILVEIRA, D.G.; SOUZA, F.V.D.; PELACANI, C.R.; SOUZA, A.S.; LEDO, C.A.S.; SANTANA, J.R.F. Micropropagation and in vitro Conservation of Neoglaziovia variegata (Arr. Cam.) Mez, a Fiber Producing Bromeliad from Brazil. Brazilian Archives of Biology and Technology, v.52, n.4, p.923-932, 2009.

SIQUEIRA FILHO, J.A. Flora das Catingas do Rio São Francisco: história natural e conservação. Rio de Janeiro: Editora Andrea Jakobsson, 2012. 556p.

SOUZA, V.C.; BORTOLUZZI, R.L.C. Senna - Lista de Espécies da Flora do Brasil. Jardim Botânico do Rio de Janeiro. 2011. Disponível em: <http://floradobrasil. jbrj.gov.br/jabot/floradobrasil/FB19079> Acesso em: 24 de julho de 2015 .

STUMPF, E.R.T.; BARBIERI, R.L.; FISCHER, S.Z.; HEIDEN, G.; NEITZKE, R.S. Uso ornamental de Andropogon bicornis L. (Poaceae). Revista Ceres, v.56, n.2. p.186-192, 2009.

STUMPF, E.R.T.; BARBIERI, R.L.; HEIDEN, G.; FISCHER, S.Z; NEITZKE, R.S. Potencialidade ornamental de espécies de Eryngium (Apiaceae) ocorrentes nos campos do Rio Grande do Sul. Magistra, v.20, n.3, p.256-263, 2008. 
STUMPF, E.R.T.; HEIDEN, G.; BARBIERI, R.L.; FISCHER, S.Z.; NEITZKE, R.S.; ZANCHET, B.; GROLLI, P.R. Método para avaliação da potencialidade ornamental de flores e folhagens de corte nativas e não convencionais. Revista Brasileira de Horticultura Ornamental, v.13, n.2, p.143-148, 2007.

TOMBOLATO, A.F.C. Potencial ornamental das espécies nativas. Revista Brasileira de Horticultura Ornamental, v.14, n.1, p. 27-28, 2008.
WEISS, D. Introduction of new cut flowers, domestication of new species and introduction of new traits not found in commercial varieties. In: Vainstein, A. Breeding for Ornamentals: Classical and Molecular Approaches. Dordrecht: Kluwer Academic Publishers, 2002. p.129-137. 